\title{
Phytochemical analysis and cellular uptake study of an Ayurvedic formulation, Vyaghryadi Kashayam used in the clinical management of COVID-19.
}

\section{Nandakumar G*, Deepu Mohanan, Minsha MG, Rammanohar P.}

Amrita Center for Advanced Research in Ayurveda (ACARA), Amrita School of Ayurveda, Amrita Vishwa Vidyapeetham, Amritapuri, Kollam, Kerala - 690525, India

*Corresponding author: nandakumarg705@gmail.com

Abstract: Repurposing of drugs is one of the ways to combat COVID-19 and Traditional Chinese Medicine set a precedence for such an approach at the outset of the pandemic. In India, the Ministry of AYUSH has recommended a number of formulations in clinical management of COVID-19. Vyaghryadi Kashayam (VK) is a classical formulation indicated in the management of Vatakaphajvara (a type of fever) which is amongst the medicines recommended for management of COVID-19. The constituents of VK are Zingiber officinale Roscoe, Tinospora cordifolia (Thunb.) Miers and Solanum xanthocarpum Schrad \& Wendl. A chemical profile of VK was generated using HPTLC and LC-MS/MS QTOF. Out of the 31 identified phytochemicals in VK, it was found that seven have been reported to have activity against SARS-CoV-2 in prior docking studies. Cellular uptake studies of VK in Caco2 cells showed that all these seven phytochemicals were absorbed by the cells. These findings provide preliminary hints about the potential of VK in clinical management of COVID-19. Further confirmatory in-vitro studies are warranted before large scale clinical studies are initiated.

Keywords: SARS-CoV-2, COVID-19, Vyaghryadi Kashayam, Ayurveda, ACE2 receptors, Mpro, Spike protein, Phytochemistry.

\section{Introduction}

Ever since the outbreak of COVID-19 in India, Ayurvedic practitioners have responded to the pandemic with treatment protocols [1] . Based on the clinical profile of COVID-19, the Ministry of AYUSH (MoA) has recommended a number of formulations for clinical management of the disease. Formulations such as Ayush Kwath [2] have been widely recommended to support immunity as a preventive measure. Vyaghryadi Kashayam (VK) is a classical Ayurvedic formulation listed by MoA[3] for management of symptomatic COVID- 
19. Sunthi or Ginger (Zingiber officinale Roscoe), Guduchi or Giloy (Tinospora cordifolia (Thunb.) Miers) and Kantakari (Solanum xanthocarpum Schrad and Wendl) are the three ingredients of this formulation[4]. Zingiber officinale Roscoe (ZO) is considered as a good anti-viral drug [5] and has been used for treating cough, respiratory tract infections, and bronchitis in Ayurveda[6]. Tinospora cordifolia (Thunb.) Miers (TC) is a very good source of anti-viral phytochemicals such as berberine [7] as well as immunomodulatory phytochemicals such as cordifolioside A and syringin [8]. It is used in Ayurveda for management of fevers and for immunomodulation[9]. Solanum xanthocarpum Schrad \& Wendl (SX) is used in ayurveda against asthma and respiratory diseases[10].

Drug repurposing has been a predominant approach deployed against the coronavirus [11]. This holds good for traditional systems of medicine in India too [12]. Liqourice (Glycyrrhiza glabra)[13] Ashwagandha (Withania somnifera) [14], and TC [15] are amongst the herbs that have been studied most for activity against SARS-CoV-2. In-silico molecular docking studies of the constituent phytochemicals in the plants have revealed their potential to bind to parts of the virus, be it the main protease(Mpro) [16] or the spike protein[17], or to ACE2 receptors in the host [18]. These herbs have also been included in clinical studies related to COVID-19. ZO and SX have also been reported to contain chemical constituents with potential activity against SARS-CoV-2. With this background, we generated a chemical profile for VK using HPTLC and LC-MS\MS QTOF.

The main objective of the study was to identify phytochemicals present in VK that have been recognised to have potential activity against SARS-CoV-2. The secondary objective was to study the cellular uptake of the phytochemicals present in VK. An additional objective was to compare the phytochemical profile of individual herbs with that of the prepared VK decoction.

\section{Materials and Methods}

\subsection{Kashayam preparation}

The constituent drugs were identified and authenticated. VK was made by taking $10 \mathrm{~g}$ each of the constituent drugs and to the mixture, $480 \mathrm{ml}$ water was added and then boiled till the volume was reduced to $60 \mathrm{ml}[19]$. The individual drugs were also made into kashayam following the above method of preparation. 


\subsection{HPTLC Analysis}

\subsubsection{Sample preparation}

Around $4 \mathrm{ml}$ of VK was loaded onto a Vacuum concentrator and the water content was removed. The residue obtained was then mixed with $1 \mathrm{ml}$ methanol and then sonicated for 10 min. It was then centrifuged and the supernatant taken for HPTLC analysis.

\subsubsection{Instrumentation protocol}

The HPTLC analysis of sample was performed by using CAMAG HPTLC system (CAMAG, Switzerland) equipped with Linomat V applicator, CAMAG TLC Scanner 4, TLC Visualizer and winCATS software version 1.4.10. HPTLC was performed on an aluminium supported silica gel HPTLC plate $60 \mathrm{~F} 254(10 \mathrm{~cm} \times 10 \mathrm{~cm})$. Samples were loaded as bands of $8-\mathrm{mm}$ width under a flow of $\mathrm{N} 2$ gas. The bands were applied $10 \mathrm{~mm}$ apart, at a height of $8 \mathrm{~mm}$ from the plate tip. The development was carried out in the CAMAG twin trough chamber $(10 \mathrm{~cm} \times$ $10 \mathrm{~cm}$ ) with mobile phase n-hexane: acetone (6:4). The length of chromatogram ran till $70 \mathrm{~mm}$, and TLC plates were air dried in a fuming hood utilising a hair dryer with adequate ventilation before scanning.

The chromatogram was then recorded using a CAMAG Visualizer under 254nm, 366nm and white light. Densitometric scan was done using Scanner 4 under $254 \mathrm{~nm}$ and $366 \mathrm{~nm}$ from $5 \mathrm{~mm}$ to $80 \mathrm{~mm}$ to yield a densitogram.

\subsection{LC MS/MS QTOF Analysis}

\subsubsection{Sample preparation}

$25 \mathrm{mg}$ of the VK was accurately weighed and transferred into a $25 \mathrm{~mL}$ volumetric flask and made up to the mark using distilled water. About $10 \mu \mathrm{L}$ of the prepared sample is then dissolved in Methanol (LCMS grade) in $10 \mathrm{~mL}$ volumetric flask and further diluted again for obtaining the sample in ppb concentration with respect to the active compounds present in them. The diluted sample in ppb concentration is used for the identification of phytochemicals via LCMS/MS QTOF.

\subsubsection{LC-MS/MS QTOF Analysis}


The diluted sample was filtered through PVDF membrane filter (polyvinylidene fluoride, 0.2 $\mu \mathrm{m})$ before the filtrate was taken for LC-MS/MS QTOF analysis. The analysis was performed on Agilent 6545 tandem mass Q-TOF LC-MS/MS coupled with Agilent LC 1260 equipped with Agilent infinity lab poroshell C18 column of $2.1 \mathrm{~mm} \times 500 \mathrm{~mm} 1.8 \mu$. Gradient elution was performed with $0.1 \%$ formic acid solution (solvent A) and methanol (solvent B) at a constant flow rate of $0.3 \mathrm{mLmin}-1.0 \mathrm{~min} 10 \% \mathrm{~B} ; 3 \mathrm{~min} 20 \% \mathrm{~B} ; 16 \mathrm{~min} 22 \% \mathrm{~B} ; 17 \mathrm{~min} 50 \% \mathrm{~B} ; 19 \min$ $60 \%$; $20-23 \min 95 \% ; 25 \min 90 \% ; 30 \min 5 \%$. Column temperature was maintained at $37^{\circ} \mathrm{C}$. The MS analysis was accomplished using ESI in the positive mode. The analysis conditions for MS were drying gas (nitrogen) flow $10 \mathrm{Lmin}-1$; nebulizer pressure 40 psi; drying gas temperature $325^{\circ} \mathrm{C}$; capillary voltage-4000 V; fragmentor volt $175 \mathrm{~V}$; Oct RF Vpp $750 \mathrm{~V}$. The mass fragmentation was performed by auto MS mode.

\subsection{Cell culture}

\section{$\underline{\text { 2.4.1 MTT Assay }}$}

Caco 2 cells were plated into a 96-well culture plate at a density of $10^{4}$ cells $/ \mathrm{mL}$, and allowed to attach for 24 hours. VK was then diluted to appropriate concentrations. All the samples were filter sterilized using $0.2 \mu \mathrm{m}$ syringe filters and immediately applied to the cells. Dosedependent cytotoxicity was assessed by exposing cells to the VK at different concentrations such as VK1 (undiluted), VK10 (diluted 10 times) and VK100 (diluted 100 times) for 5 days. Viability of the cells was evaluated using the MTT reduction method. The cells were incubated with MTT for four hours, and $200 \mu \mathrm{L}$ dimethyl sulfoxide was then added to each well to dissolve the dark blue crystal. The experiment was repeated 3 times (triplicates). An optical density of $550 \mathrm{~nm}$ was used inside the Microplate reader to monitor cell viability.

\subsubsection{Cellular Uptake Assay}

Caco2 cells (400 cells $/ \mathrm{ml}$ ) were suspended in $1 \mathrm{ml}$ of culture media containing different concentrations of the dissolved sample in a glass tube and then were incubated at $37^{\circ} \mathrm{C}$ in an atmosphere of 5\% CO2 and 95\% air (incubator) for 2 hours. After incubation, the cell suspension was centrifuged at $2000 \mathrm{rpm}$ for 2 minutes at $4{ }^{\circ} \mathrm{C}$. The supernatant was then removed and cells were rinsed with $1 \mathrm{ml}$ of ice-cold PBS (1X; pH 7.25) and centrifuged at 1000 rpm for 1 minute at $4^{\circ} \mathrm{C}$. After centrifugation, supernatant was again removed and $1 \mathrm{ml}$ of cytosol buffer ( $\mathrm{pH} 7.5,10 \mathrm{mM}$-Tris-HCL, 1mM EDTA, 1mM MgCl2) was added. The solution 
was kept on ice for 5 minutes before cells were sonicated with a probe sonicator and transferred to Eppendorf tubes. The cells were then centrifuged at $14,000 \mathrm{rpm}$ for 25 minutes at $4^{\circ} \mathrm{C}$. The supernatant was used to determine the phytochemicals absorbed by cells using LC-MS/MS QTOF.

\subsection{Compilation of Phytochemicals}

A literature search was done using search engine "PubMed" which yielded 51 articles using the keywords "SARS-CoV-2", "phytochemical", "docking". These articles were then checked to prepare a list of phytochemicals that have positive results from In-silico docking studies. This compilation was further used to screen the phytochemicals identified from the kashayam.

\subsection{Screening of Phytochemicals}

Phytochemicals that were found to be present in the kashayam were noted. These were then divided into two groups on the basis whether any of them had been reported previously to have interaction with SARS-CoV-2. Further, identification of the phytochemicals that get absorbed from the kashayam was done using Caco 2 cell line studies. Caco 2 cell line was chosen as it is the commonly used cell line to find out cellular uptake[20].

\section{Reagents and Chemicals}

\subsection{HPTLC Analysis}

n-hexane (HPLC grade, Merck), acetone (HPLC grade, Merck), Methanol (HPLC grade, Merck)

\section{$\underline{\text { LC MS/MS QTOF Analysis }}$}

Methanol (LCMS grade, J T baker), Formic acid (Lichropur, Merck), Deionised water (Sartorius)

\section{Results}

In the developed TLC plate, using n-hexane: acetone (6:4) as mobile phase, the first track represents ZO kashayam. The second track is TC kashayam, third track is SX kashayam and fourth is VK kashayam. The developed plates were viewed under $254 \mathrm{~nm}$ illumination and 
366nm illumination (Fig 1). The TLC plate, which was derivatized using anisaldehyde sulphuric acid reagent was viewed under white light illumination (Fig 2).
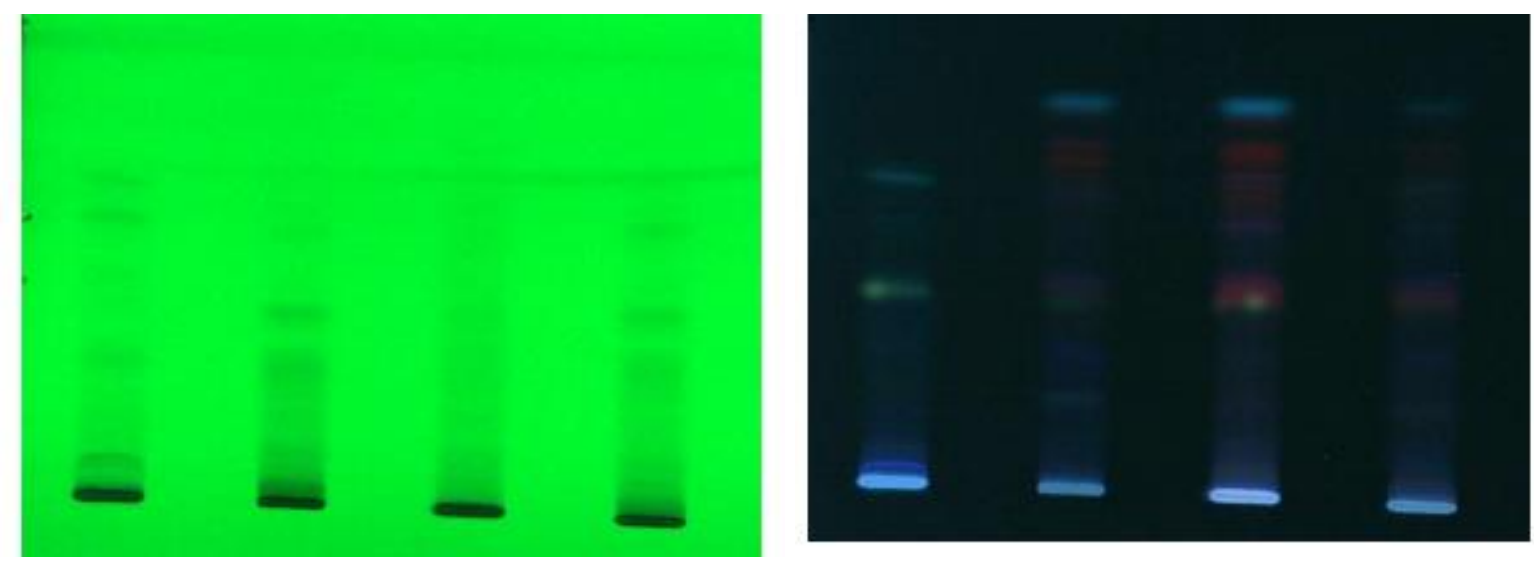

Fig 1: Developed plates under $254 \mathrm{~nm}$ and $366 \mathrm{~nm}$ illumination respectively

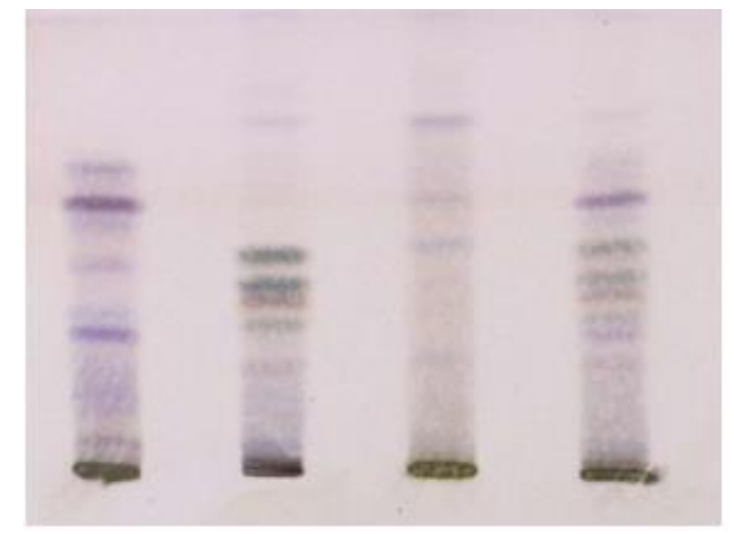

Fig 2: Derivatized plate under white light

The similarity in the generated profiles are summarised in Table 1. Bands showing the same $\mathrm{Rf}$ values in the different tracks are noted down to draw comparison between the $\mathrm{VK}$ and its ingredients. 
Table 1: Similarities between the profile of VK and its ingredients

\begin{tabular}{|c|c|c|c|}
\hline Illumination & Plate & $\begin{array}{c}\text { Similarities } \\
\text { in tracks }\end{array}$ & $\begin{array}{c}\text { Similarities } \\
\text { in drugs }\end{array}$ \\
\hline $254 \mathrm{~nm}$ & Developed plate & $\begin{array}{l}\text { Bands of track } 2 \text { and track } 4 \text { at } \mathrm{Rf} \\
\text { values } 0.26,0.31,0.39,0.49,0.89 \\
\text { Bands of track } 3 \text { and track } 4 \text { at } \mathrm{Rf} \\
\text { value: } 0.61,0.69\end{array}$ & $\begin{array}{l}\text { TC kashayam and } \\
\text { VK. } \\
\text { SX kashayam and VK }\end{array}$ \\
\hline $366 \mathrm{~nm}$ & Developed plate & $\begin{array}{l}\text { Bands of track } 3 \text { and track } 4 \text { at } \mathrm{Rf} \\
\text { value: } 0.68 \\
\text { Bands of track } 2 \text { and track } 4 \text { at } \mathrm{Rf} \\
\text { value: } 0.64\end{array}$ & $\begin{array}{l}\text { SX kashayam and VK } \\
\text { TC kashayam and } \\
\text { VK. }\end{array}$ \\
\hline White light & $\begin{array}{l}\text { Derivatized plate } \\
\text { (Anisaldehyde } \\
\text { sulphuric acid } \\
\text { reagent) }\end{array}$ & $\begin{array}{l}\text { Major band of track } 1 \text { and track } \\
4 \text { at Rf values: } 0.60,0.70 \\
\text { Bands of track } 2 \text { and track } 4 \text { at Rf } \\
\text { values } 0.40,0.50\end{array}$ & $\begin{array}{l}\text { ZO kashayam and } \\
\text { VK. } \\
\text { TC kashayam and } \\
\text { VK. }\end{array}$ \\
\hline
\end{tabular}

The HPTLC analysis shows that the profile of VK is strikingly similar to that of TC, which is one of the most clinically utilised herb in management of COVID-19 [21]. Also TC being a very good source of antivirals as well as immunomodulatory phytochemicals could be the main contributor to the action of $\mathrm{VK}$.

\subsection{LC-MS/MS QTOF ANALYSIS}


The Total ion chromatogram (TIC) obtained after the analysis of VK has been illustrated in the Fig- 3. The peaks were evaluated based on the MS/MS fragmentation pattern obtained by collision induced dissociation (CID). About 31 phytochemicals (Table-2) were identified from the VK by LC-MS/MS QTOF analysis.

Table-2: The 31 phytochemicals identified using LC-MS/MS QTOF analysis followed by the library search (Find by Formula) from VK sample.

\begin{tabular}{|l|l|l|l|l|}
\hline Sl.no & RT (Min) & Molecular formula & Name & $\mathrm{m} / \mathrm{z}$ \\
\hline 1 & 6.828 & $\mathrm{C}_{17} \mathrm{H}_{26} \mathrm{O}_{4}$ & 6-Gingerol & 317.1719 \\
\hline 2 & 7.028 & $\mathrm{C}_{19} \mathrm{H}_{30} \mathrm{O}_{4}$ & 8-Gingerol & 340.2472 \\
\hline 3 & 7.094 & $\mathrm{C}_{17} \mathrm{H}_{24} \mathrm{O}_{3}$ & 6-Shogaol & 277.1796 \\
\hline 4 & 7.011 & $\mathrm{C}_{21} \mathrm{H}_{32} \mathrm{O}_{3}$ & 10 -Shogaol & 350.2682 \\
\hline 5 & 7.011 & $\mathrm{C}_{19} \mathrm{H}_{28} \mathrm{O}_{3}$ & 8-Shogaol & 322.2369 \\
\hline 6 & 7.094 & $\mathrm{C}_{17} \mathrm{H}_{26} \mathrm{O}_{3}$ & 6-Paradol & 301.1771 \\
\hline 7 & 7.31 & $\mathrm{C}_{17} \mathrm{H}_{22} \mathrm{O}_{4}$ & 1-dehydro-6-Gingerdione & 313.1401 \\
\hline 8 & 6.895 & $\mathrm{C}_{22} \mathrm{H}_{34} \mathrm{O}_{6}$ & Methyldiacetoxy-6-gingerdiol & 417.2236 \\
\hline 9 & 6.562 & $\mathrm{C}_{19} \mathrm{H}_{28} \mathrm{O}_{6}$ & Diacetoxy-4-gingerdiol & 353.1946 \\
\hline 10 & 5.865 & $\mathrm{C}_{9} \mathrm{H}_{10} \mathrm{O}_{5}$ & Syringic acid & 221.0418 \\
\hline 11 & 5.3 & $\mathrm{C}_{7} \mathrm{H}_{6} \mathrm{O}_{4}$ & Gentisic acid & 155.0338 \\
\hline 12 & 5.865 & $\mathrm{C}_{7} \mathrm{H}_{6} \mathrm{O}_{5}$ & Gallic acid & 171.0283 \\
\hline 13 & 0.531 & $\mathrm{C}_{4} \mathrm{H}_{6} \mathrm{O}_{5}$ & Malic acid & 152.0563 \\
\hline 14 & 7.161 & $\mathrm{C}_{21} \mathrm{H}_{18} \mathrm{O}_{13}$ & Miquelianin & 496.1085 \\
\hline 15 & 6.546 & $\mathrm{C}_{10} \mathrm{H}_{8} \mathrm{O}_{3}$ & 4-Methylumbelliferone & 177.0541 \\
\hline 16 & 8.706 & $\mathrm{C}_{9} \mathrm{H}_{6} \mathrm{O}_{3}$ & Umbelliferone & 163.0387 \\
\hline 17 & 6.197 & $\mathrm{C}_{11} \mathrm{H}_{12} \mathrm{O}_{5}$ & Sinapic acid & 247.0557 \\
\hline 18 & 6.33 & $\mathrm{C}_{7} \mathrm{H}_{6} \mathrm{O}_{3}$ & 4-Hydroxybenzoic acid & 139.0387 \\
\hline 19 & 5.316 & $\mathrm{C}_{20} \mathrm{H}_{24} \mathrm{~N}_{4}$ & Magnoflorine & 343.1748 \\
\hline 20 & 8.307 & $\mathrm{C}_{22} \mathrm{H}_{34} \mathrm{O}_{3}$ & Anacardic acid & Diosmetic \\
\hline 21 & 6.612 & $\mathrm{C}_{16} \mathrm{H}_{12} \mathrm{O}_{6}$ & & 36705 \\
\hline
\end{tabular}




\begin{tabular}{|l|l|l|l|l|}
\hline 22 & 6.33 & $\mathrm{C}_{21} \mathrm{H}_{20} \mathrm{O}_{10}$ & Apigetrin & 433.1143 \\
\hline 23 & 7.144 & $\mathrm{C}_{13} \mathrm{H}_{16} \mathrm{O}_{9}$ & Protocatechuic acid-4-glucoside & 317.0848 \\
\hline 24 & 5.399 & $\mathrm{C}_{8} \mathrm{H}_{8} \mathrm{O}_{4}$ & Vanilic acid & 169.0489 \\
\hline 25 & 5.981 & $\mathrm{C}_{15} \mathrm{H}_{18} \mathrm{O}_{8}$ & Bilobalide & 349.09 \\
\hline 26 & 6.596 & $\mathrm{C}_{27} \mathrm{H}_{43} \mathrm{~N} \mathrm{O}_{2}$ & Solanacarpidine & 414.3341 \\
\hline 27 & 6.214 & $\mathrm{C}_{45} \mathrm{H}_{73} \mathrm{~N} \mathrm{O}_{16}$ & Solasonine & 884.4977 \\
\hline 28 & 6.23 & $\mathrm{C}_{45} \mathrm{H}_{73} \mathrm{~N} \mathrm{O}_{15}$ & Solamargine & 868.5051 \\
\hline 29 & 4.768 & $\mathrm{C}_{9} \mathrm{H}_{6} \mathrm{O}_{4}$ & Asculetin & 201.0182 \\
\hline 30 & 6.064 & $\mathrm{C}_{15} \mathrm{H}_{16} \mathrm{O}_{9}$ & Aesculine & 363.0707 \\
\hline 31 & 8.34 & $\mathrm{C}_{30} \mathrm{H}_{50} \mathrm{O}$ & Cycloartenol & 444.4171 \\
\hline
\end{tabular}

Using the Library search option "Find By Formula (FBF)" available in the Agilent 6545 LCMS/MS QTOF system more than 60 compounds have been identified. However, only 31 compounds showed a matching score greater than or equal to 75.0 out of 100 (Table-2).

\subsubsection{Screening of Phytochemicals}

As per a literature search, a compilation of phytochemicals that had been reported to have action against SARS-CoV-2 was created. Screening of the phytochemicals, as obtained from LC-MS/MS QTOF analysis, revealed that seven phytochemicals that are present in VK have been reported previously for potential activity against SARS-CoV-2. These are 6-gingerol [22], 6- shogoal[22], Diacetoxy-4 -gingerdiol [23], gallic acid[24], magnoflorine[24], solasonine[25] and solamargine[25]. The binding site of these phytochemicals from the previous reports and the plant sources of these are summarised in Table 3.

Table 3: Phytochemicals and their binding sites from docking studies.

\begin{tabular}{|l|l|l|}
\hline Plant source & Phytochemical & Binding sites \\
\hline ZO & 6-Gingerol & M pro of SARS COV 2 \\
\hline ZO & 6-Shogoal & M pro of SARS COV 2 \\
\hline ZO & Diacetoxy-4-gingerdiol & M pro of SARS COV 2 \\
\hline TC & Gallic acid & $\begin{array}{l}\text { M pro or Cl pro of SARS } \\
\text { COV 2 }\end{array}$ \\
\hline TC & Magnoflorine & $\begin{array}{l}\text { M pro or Cl pro of SARS } \\
\text { COV 2 }\end{array}$ \\
\hline
\end{tabular}




\begin{tabular}{|l|l|l|}
\hline SX & Solasonine & ACE2 receptor \\
\hline SX & Solamargine & ACE2 receptor \\
\hline
\end{tabular}

All seven of these were also found to be absorbed by Caco2 cells. In order to establish the overall action of VK against SARS-CoV-2 we need further in vitro testing, however, the presence of such phytochemicals could help validate the usage of VK against COVID-19.

\subsection{Cell Culture:}

\subsubsection{MTT ASSAY}

Table 4 shows the absorbance values obtained at 550nm for the respective samples. The experiment was done in triplicates and the average of the three values was determined.

Table 4: Absorbance values @ 550nm for the different concentrations of VK

\begin{tabular}{|c|c|c|c|}
\hline Sample & VK 100 & VK 10 & VK 1 \\
\hline $\begin{array}{c}\text { Exp 1 } \\
\text { value }\end{array}$ & 0.906 & 0.387 & 0.166 \\
\hline $\begin{array}{c}\text { Exp 2 } \\
\text { value }\end{array}$ & 0.873 & 0.358 & 0.252 \\
\hline $\begin{array}{c}\text { Exp 3 } \\
\text { value }\end{array}$ & 0.899 & 0.290 & 0.194 \\
\hline Average & $\mathbf{0 . 8 9 2}$ & $\mathbf{0 . 3 4 5}$ & $\mathbf{0 . 2 0 4}$ \\
\hline
\end{tabular}

These average values are noted and used to make a graph which helps identify the LD50 value. The plot between absorbance of the solution and concentration of cells shows a sharp inclination between V10 and V100. 


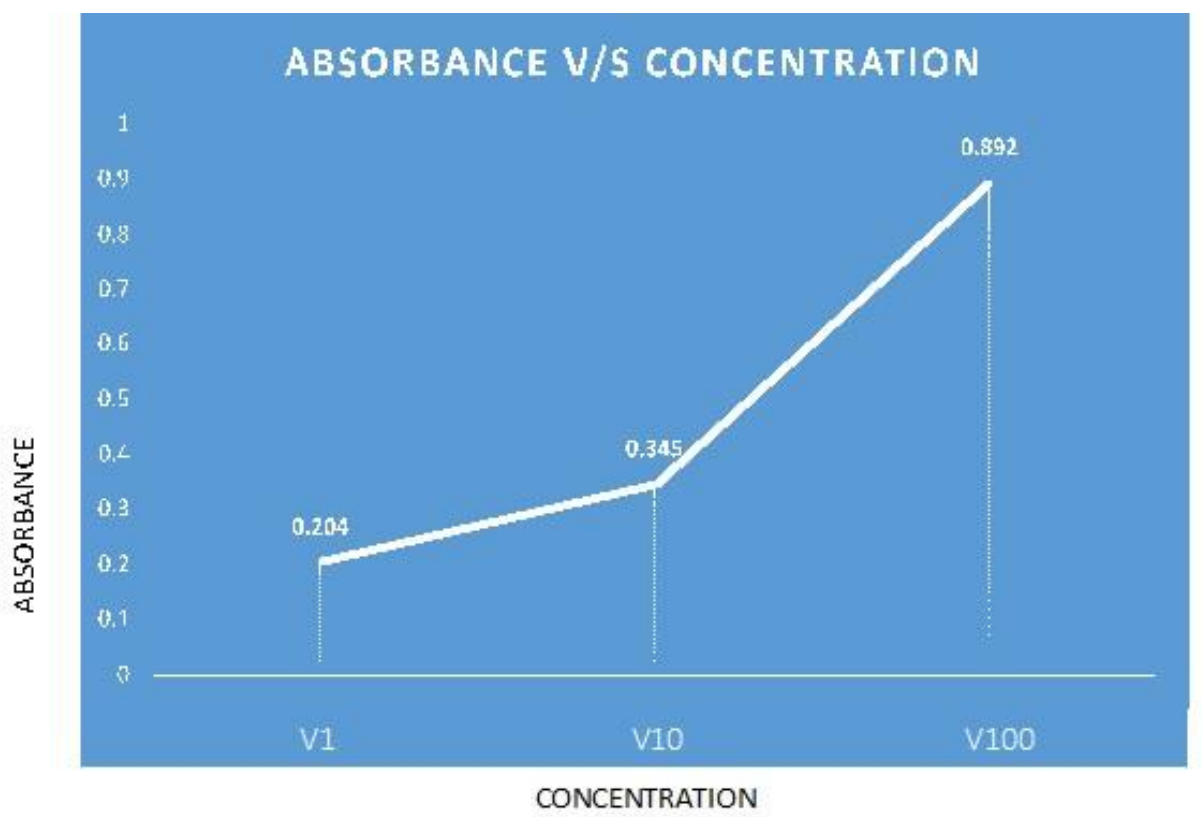

Fig 3: Graphical representation for the determination of LD50 value

From the graph, LD50 value can be assumed to be between V10 and V100 owing to the increase of the inclination or slope.

\subsubsection{Cellular Uptake study}

Cellular uptake study was done to identify the phytochemicals absorbed by cells from the VK. The LC-MS/MS QTOF analysis found that all the seven phytochemicals with reported activity against SARS-CoV-2 were absorbed by the Caco2 cells (Figure-4).

The ion at $6.828 \mathrm{~min}$ showed an $\mathrm{m} / \mathrm{z}$ value 317.1719 was identified as 6-Gingerol by find by formula method using the Agilent mass hunter software. Similarly, the molecular ion at 7.094 min corresponds to 6-Shogaol with $\mathrm{m} / \mathrm{z}$ value 277.1796. The phytochemical Diacetoxy-4gingerdiol with an $\mathrm{m} / \mathrm{z}$ ratio 353.1946 recognized at $6.562 \mathrm{~min}$ from the TIC. Gallic acid with $\mathrm{m} / \mathrm{z}$ value 171.0283 has been found at $5.865 \mathrm{~min}$. The molecular ion peak at $5.316 \mathrm{~min}$ corresponds to the phytochemical Magnoflorine having an $\mathrm{m} / \mathrm{z}$ ratio 343.1748 . The ion peaks at 6.214 and 6.23 were identified as solasonine and solamargine respectively with their corresponding $\mathrm{m} / \mathrm{z}$ value 884.4977 and 868.5051 .

Several other phytochemicals were also found to have been absorbed by the cell line which are not yet reported to have action against SARS-CoV-2. 


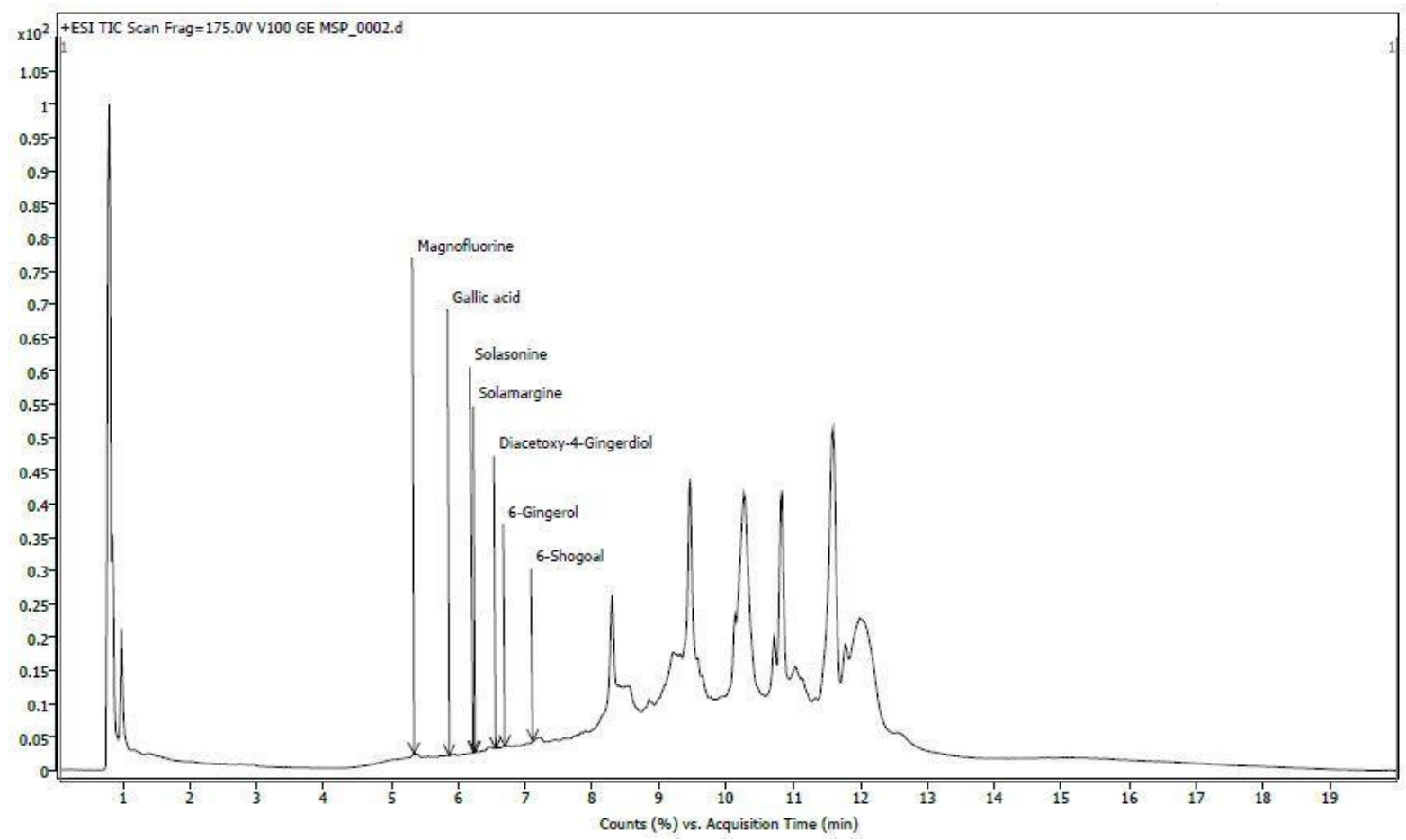

Fig 4: The total ion chromatogram of Caco2 cells after cellular uptake of VK having a concentration V50.

\section{Discussion}

Ayurveda experts have suggested that COVID-19 presents with features comparable to Vatakaphajvara, which can become Sannipatajvara [26][27][28] with severe presentation, complications and even death in some patients. VK is indicated for the management of Vatakaphajvara and hence has been recommended for management of COVID-19.

The presence of phytochemicals having a potential to bind to ACE2 receptors of host or Mpro of SARS-CoV-2 in VK lends support to its role in treating COVID-19. Cellular uptake of few other phytochemicals from VK were also observed, which have not been investigated for activity against SARS-CoV-2.

This work provides preliminary hints through phytochemical analysis that supports the selection of VK by Ayurveda physicians for the management of COVID-19. It also points out how a critical analysis of Ayurvedic texts can yield interesting leads for repurposing traditional herbal formulations for management of emerging diseases.

\section{Limitations}


The limitations of this study are listed below;

- VK is administered by adding powder of Piper longum (PL) to the prepared decoction. PL contains piperine as the major compound which is known to enhance bioavailability[29] of the phytochemicals. Due to the non-availability of standards, the quantification of absorbed phytochemicals was not possible and so we could not assess whether addition of PL powder could enhance cellular uptake of the phytochemicals.

- The evidence supporting the potential activity of phytochemicals identified from VK against SARS-CoV-2 has been generated from in silico studies. Confirmatory in-vitro studies need to be done before definite conclusion can be drawn about the efficacy of VK in management of COVID-19.

- VK is a complex mixture of phytochemicals. This study has not looked at the possible interactions and synergism of the chemical constituents of VK which can influence the pharmacological activity of the formulation as a whole.

- We could not assess the biotransformation of the phytochemicals during the process of digestion, due to the non-availability of digestive enzymes.

\section{Conclusion}

The presence of seven phytochemicals in VK that have been reported to have potential activity against SARS-CoV-2 provides preliminary indications about the utility of this formulation in management of COVID-19. Further confirmatory in-vitro studies of these phytochemicals are warranted. Docking studies for activity against SARS-CoV-2 of other phytochemicals present in VK exhibiting significant cellular uptake are recommended.

\section{Conflict of interest}

None declared 


\section{Sources of funding}

Nil

\section{References}

[1] S. Rastogi, D.N. Pandey, R.H. Singh, COVID-19 pandemic: A pragmatic plan for ayurveda intervention, J. Ayurveda Integr. Med. (2020). https://doi.org/10.1016/j.jaim.2020.04.002.

[2] S. Gautam, A. Gautam, S. Chhetri, U. Bhattarai, Immunity against COVID-19: Potential role of Ayush Kwath, J. Ayurveda Integr. Med. (2020). https://doi.org/10.1016/j.jaim.2020.08.003.

[3] Guidelines for AYUSH clinical studies in COVID-19, (n.d.). https://www.ayush.gov.in/docs/clinical-protocol-guideline.pdf.

[4] Hari Sadashiva Shastri, ed., Astangahrdayam of Vagbhata, P.555 (Cikitsasthana, 1.61), Chaukhambha Publications, New Delhi, 2016.

[5] S. Kaushik, G. Jangra, V. Kundu, J.P. Yadav, S. Kaushik, Anti-viral activity of Zingiber officinale (Ginger) ingredients against the Chikungunya virus, VirusDisease. 31(2020) 270-276. https://doi.org/10.1007/s13337-020-00584-0.

[6] Yadavji Trikamji Acarya, ed., Carakasamhita of Caraka, P.486 (Cikitsasthana, 12.47-48), Chaukhambha Sanskrit Sansthan, New Delhi, 2017.

[7] F.S. Varghese, B. Thaa, S.N. Amrun, D. Simarmata, K. Rausalu, T.A. Nyman, A. Merits, G.M. Mclnerney, L.F.P. Ng, T. Ahola, The Antiviral Alkaloid Berberine Reduces Chikungunya VirusInduced Mitogen-Activated Protein Kinase Signaling, J. Virol. 90 (2016) 9743-9757. https://doi.org/10.1128/jvi.01382-16.

[8] U. Sharma, M. Bala, N. Kumar, B. Singh, R.K. Munshi, S. Bhalerao, Immunomodulatory active compounds from Tinospora cordifolia, J. Ethnopharmacol. 141 (2012) 918-926. https://doi.org/10.1016/j.jep.2012.03.027.

[9] A. Kamra Verma, V.K. Anita, Assessment of the Multifaceted Imm unomodulatory Potential of the Aqueous Extract of Tinospora Cordifolia, 2011. www.isca.in (accessed January 28, 2021).

[10] S. Govindan, S. Viswanathan, V. Vijayasekaran, R. Alagappan, A pilot study on the clinical efficacy of Solanum xanthocarpum and Solanum trilobatum in bronchial asthma, J. Ethnopharmacol. 66 (1999) 205-210. https://doi.org/10.1016/S0378-8741(98)00160-3. 
[11] J. Santos, S. Brierley, M.J. Gandhi, M.A. Cohen, P.C. Moschella, A.B.L. Declan, Repurposing therapeutics for potential treatment of SARS-CoV-2: A review, Viruses. 12 (2020). https://doi.org/10.3390/v12070705.

[12] S. Kumar Singh, K. Rajoria, Sanjeev Sharma, Principles of Rajayakshma management for COVID-19, J. Ayurveda Integr. Med. (2020). https://doi.org/10.1016/j.jaim.2020.08.002.

[13] S.K. Sinha, S.K. Prasad, M.A. Islam, S.S. Gurav, R.B. Patil, N.A. AlFaris, T.S. Aldayel, N.M. AlKehayez, S.M. Wabaidur, A. Shakya, Identification of bioactive compounds from Glycyrrhiza glabra as possible inhibitor of SARS-CoV-2 spike glycoprotein and non-structural protein-15: a pharmacoinformatics study, J. Biomol. Struct. Dyn. (2020) 1-15. https://doi.org/10.1080/07391102.2020.1779132.

[14] R. V. Chikhale, S.S. Gurav, R. B. Patil, S.K. Sinha, S.K. Prasad, A. Shakya, S.K. Shrivastava, N.S. Gurav, R.S. Prasad, Sars-cov-2 host entry and replication inhibitors from Indian ginseng: an insilico approach, J. Biomol. Struct. Dyn. (2020) 1-12. https://doi.org/10.1080/07391102.2020.1778539.

[15] S. Krupanidhi, K. Abraham Peele, T.C. Venkateswarulu, V.S. Ayyagari, M. Nazneen Bobby, D. John Babu, A. Venkata Narayana, G. Aishwarya, Screening of phytochemical compounds of Tinospora cordifolia for their inhibitory activity on SARS-CoV-2: an in silico study, J. Biomol. Struct. Dyn. (2020) 1-5. https://doi.org/10.1080/07391102.2020.1787226.

[16] R. Islam, M.R. Parves, A.S. Paul, N. Uddin, M.S. Rahman, A. Al Mamun, M.N. Hossain, M.A. Ali, M.A. Halim, A molecular modeling approach to identify effective antiviral phytochemicals against the main protease of SARS-CoV-2, J. Biomol. Struct. Dyn. (2020). https://doi.org/10.1080/07391102.2020.1761883.

[17] P. Pandey, J.S. Rane, A. Chatterjee, A. Kumar, R. Khan, A. Prakash, S. Ray, Targeting SARS-CoV2 spike protein of COVID-19 with naturally occurring phytochemicals: an in silico study for drug development, J. Biomol. Struct. Dyn. (2020) 1-11. https://doi.org/10.1080/07391102.2020.1796811.

[18] A. Basu, A. Sarkar, U. Maulik, Molecular docking study of potential phytochemicals and their effects on the complex of SARS-CoV2 spike protein and human ACE2, Sci. Rep. 10 (2020) 115. https://doi.org/10.1038/s41598-020-74715-4.

[19] Ayurvedic Formulatory of India Vol I, Part B appendice, (n.d.). https://dravyagunatvpm.files.wordpress.com/2009/02/afi-vol-i_part_b_appendices.pdf 
(accessed January 29, 2021).

[20] J. Boyer, D. Brown, A. Rui, H. Liu, Uptake of Quercetin and Quercetin 3-Glucoside from Whole Onion and Apple Peel Extracts by Caco-2 Cell Monolayers, (2004).

https://doi.org/10.1021/jf030733d.

[21] V. Bhapkar, T. Sawant, S. Bhalerao, A critical analysis of CTRI registered AYUSH studies for COVID- 19, J. Ayurveda Integr. Med.(2020). https://doi.org/10.1016/j.jaim.2020.10.012.

[22] S. Garg, A. Anand, Y. Lamba, A. Roy, Molecular docking analysis of selected phytochemicals against SARS-CoV-2 Mpro receptor, Vegetos. 33 (2020) 766-781. https://doi.org/10.1007/s42535-020-00162-1.

[23] F. Mosquera-Yuqui, N. Lopez-Guerra, E.A. Moncayo-Palacio, Targeting the 3CLpro and RdRp of SARS-CoV-2 with phytochemicals from medicinal plants of the Andean Region: molecular docking and molecular dynamics simulations, J. Biomol. Struct. Dyn. (2020). https://doi.org/10.1080/07391102.2020.1835716.

[24] M. Rajendran, S. Roy, K. Ravichandran, B. Mishra, D.K. Gupta, S. Nagarajan, R.C. Arul Selvaraj, I. Provaznik, In silico screening and molecular dynamics of phytochemicals from Indian cuisine against SARS-CoV-2 MPro, J. Biomol. Struct. Dyn. (2020) 1-15. https://doi.org/10.1080/07391102.2020.1845980.

[25] R.K. Goyal, J. Majeed, R. Tonk, M. Dhobi, B. Patel, K. Sharma, S. Apparsundaram, Current targets and drug candidates for prevention and treatment of SARS-CoV-2 (COVID-19) infection, Rev. Cardiovasc. Med. 21 (2020) 365-3984. https://doi.org/10.31083/j.rcm.2020.03.118.

[26] P.P. Nair, P.G. Nair, K.M. Pratap Shankar, An Ayurvedic personal ized prophylactic protocol in COVID-19, J. Ayurveda Integr. Med. (2020). https://doi.org/10.1016/j.jaim.2020.08.004.

[27] M. Goyal, Strategies and avenues for COVID-19-Ayurveda perception, AYU (An Int. Q. J. Res. Ayurveda). 40 (2019) 139. https://doi.org/10.4103/ayu.ayu_226_20.

[28] R. Puthiyedath, S. Kataria, U. Payyappallimana, P. Mangalath, V. Nampoothiri, P. Sharma, M.K. Singh, K. Kumar, N. Trehan, Ayurvedic clinical profile of COVID-19-A preliminary report, J. Ayurveda Integr. Med. (2020). https://doi.org/10.1016/j.jaim.2020.05.011.

[29] C.K. Atal, U. Zutshi, P.G. Rao, Scientific evidence on the role of Ayurvedicherbals on bioavailability of drugs, J. Ethnopharmacol. 4(1981) 229-232. https://doi.org/10.1016/03788741(81)90037-4. 
